ISSN: 2637-773X

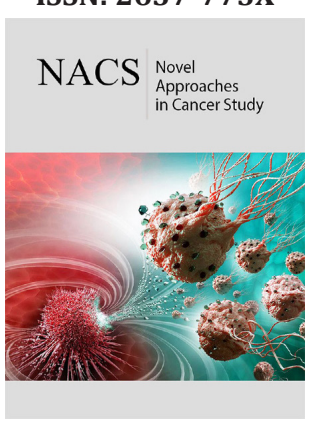

*Corresponding author: Wehrmann S, Department of General and Visceral Surgery, Chemnitz, Germany

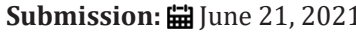

Published: 㘹June 29, 2021

Volume 6 - Issue 1

How to cite this article: Wehrmann S, Bartzsch T, Mirow L. Multimodal Approach in Histiocytic and Dendritic Cell Neoplasms. Nov Appro in Can Study. 6(1). NACS.000628. 2021. DOI: 10.31031/NACS.2021.06.000628

Copyright@ Wehrmann S, This article is distributed under the terms of the Creative Commons Attribution 4.0 International License, which permits unrestricted use and redistribution provided that the original author and source are credited.

\section{Multimodal Approach in Histiocytic and Dendritic Cell Neoplasms}

\author{
Wehrmann S*, Bartzsch T and Mirow L \\ Department of General and Visceral Surgery, Germany
}

\begin{abstract}
Histiocytic and dendritic cell neoplasms are rare but extremely aggressive tumors that represent less than $1 \%$ of all neoplasms arising in lymph nodes or soft tissues. Often the tumor is detected lately, and diagnosis is challenging both for pathologists and for clinicians. Based on the multiplicity of resembling tumors a final diagnosis is often difficult to find. Furthermore, structured therapy algorithms do not exist. Here we show our experience in diagnostics and treatment of these tumors.
\end{abstract}

\section{Opinion}

Histiocytic and dendritic cell neoplasms are rare but aggressive tumors that represent less than $1 \%$ of all neoplasms arising in lymph nodes or soft tissues. They may arise de novo or in association with T-cell, B-cell or myeloid neoplasms. These malignancies can be placed into two main groups based on their derivation from mesenchymal or bone marrow cells [1]. While Follicular Dendritic Cell Sarcoma (FDCS), Indeterminate Dendritic Cell Sarcoma (INDCS), Fibroblastic Reticular Cell Tumors (FRCT) and Disseminated Juvenile Xanthogranuloma (DJX) evolve from mesenchymal or stromal-derived dendritic cells, Histiocytic Sarcoma (HS), Langerhans Cell Histiocytosis (LCH) and Interdigitating Dendritic Cell Sarcoma (IDCS) are derived from bone marrow precursors [1,2].

Often the tumor is detected lately, and diagnosis is challenging both for pathologists and clinicians. Based on the multiplicity of resembling tumors a final diagnosis is often difficult to find. Previous case reports and case series as well as expert opinions suggest that diagnosis should be supported by imaging including CT and PET-CT followed by bioptic confirmation as well as bone marrow biopsy $[3,4]$. However, the diagnostic value of tumor-biopsy should be related to the risk of tumor expansion, especially in large ulcerating tumors. Hence the alternative of primary resection for large, ulcerating tumors without preoperative histological assessment should be discussed. Tumor-biology is not completely understood. Based on the work of the International Lymphoma Study Group we know that immunohistochemistry seems to be effective to differ the malignancies [5]. The difference between these tumors and the complexity of diagnosis is shown in Figure 1. The partial aggressive and fast growth combined with a high rate of local relapse, e.g., for HS, aggravate the decision of therapy. Prognosis of each tumor-type is different. Hence, therapy strategies have to be most individual but should start quickest possible. 


\begin{tabular}{|c|c|c|c|c|c|c|c|}
\hline & FDCS & IDCS & INDCS & HS & FRCT & DIX & LCH \\
\hline Clinical finding & Slow growing & $\begin{array}{l}\text { Solitary } \\
\text { lymphatic } \\
\text { mass, } \\
\text { aggressive }\end{array}$ & $\begin{array}{l}\text { Papules or } \\
\text { nodules on } \\
\text { the skin }\end{array}$ & $\begin{array}{l}\text { Solitary mass, } \\
\text { fast growing }\end{array}$ & Solitary mass & Small papule & $\begin{array}{c}\text { Paediatric } \\
\text { patient's } \\
\text { solitary/multifocal } \\
\text { bone/ adjacent } \\
\text { soft tissue }\end{array}$ \\
\hline Cytomorphology & $\begin{array}{l}\text { Spindle/ ovoid } \\
\text { cells with } \\
\text { whorls }\end{array}$ & $\begin{array}{c}\text { Spindle/ } \\
\text { ovoid cells } \\
\text { with whorls }\end{array}$ & $\begin{array}{c}\text { Resembles } \\
\text { Langerhans } \\
\text { cells. } \\
\text { irregular } \\
\text { nuclear } \\
\text { grooves/ } \\
\text { clefts }\end{array}$ & $\begin{array}{l}\text { Large, round, } \\
\text { focal spindling } \\
\text { areas }\end{array}$ & $\begin{array}{c}\text { Spindle/ } \\
\text { ovoid cells } \\
\text { with whorls } \\
\text { in } \\
\text { paracortical } \\
\text { areas }\end{array}$ & $\begin{array}{l}\text { Small, oval, } \\
\text { bland } \\
\text { round/oval } \\
\text { nucleus, no } \\
\text { grooves }\end{array}$ & $\begin{array}{l}\text { Large ovoid } \\
\text { epitheloid } \\
\text { histiocytes. } \\
\text { nuclear grooves }\end{array}$ \\
\hline IHC-markers & $\begin{array}{c}\text { CD4+ } \\
\text { CD21 + } \\
\text { CD23 + } \\
\text { D22-40+ } \\
\text { CD35+ } \\
\text { CD68+/- } \\
\text { Fascin + } \\
\text { Clusterin + } \\
\text { CD } 34 \text { - } \\
\text { CD1a - } \\
\text { S100 - } \\
\text { Cytokeratin - } \\
\text { HMB 5- } \\
\text { MSA - }\end{array}$ & $\begin{array}{l}\text { CD4+ } \\
\text { CD45 +/- } \\
\text { CD } 68+ \\
\text { S100+ } \\
\text { Fascin + } \\
\text { CD1a - }\end{array}$ & $\begin{array}{c}\text { CD4+ } \\
\text { CD68 +/- } \\
\text { S100+ } \\
\text { Fascin + } \\
\text { CD1a - } \\
\text { Birbeck } \\
\text { granules - }\end{array}$ & $\begin{array}{c}\text { CD68 + } \\
\text { CD } 163+ \\
\text { Lysozyme+ } \\
\text { S100 + } \\
\text { CD1a - } \\
\text { CD21 - } \\
\text { CD35 - } \\
\text { CD33 - }\end{array}$ & $\begin{array}{c}\text { Vimentin + } \\
\text { Desmin + } \\
\text { Smooth } \\
\text { muscle actin } \\
+ \\
\text { FXIIla + } \\
\text { CD21 - } \\
\text { CD35 - } \\
\text { CD1a - } \\
\text { S100- }\end{array}$ & $\begin{array}{c}\text { Vimentin + } \\
\text { sCD14 + } \\
\text { CD68 + } \\
\text { Stabilin-1 + } \\
\text { CD } 163+ \\
\text { FXIIla + } \\
\text { CD1a - }\end{array}$ & $\begin{array}{c}\mathrm{CD} 1 \mathrm{+}+ \\
\mathrm{S} 100+ \\
\text { tangerin + } \\
\text { Birbeck granules + }\end{array}$ \\
\hline \multirow{2}{*}{$\begin{array}{c}\text { BRAF mutation } \\
\text { Treatment }\end{array}$} & $19 \%$ & possible & possible & $63 \%$ & unclear & none & $50 \%-60 \%$ \\
\hline & $\begin{array}{c}\text { Surgical } \\
\text { resection + } \\
\text { adjuvant } \\
\text { chemotherapy/ } \\
\text { radiotherapy }\end{array}$ & $\begin{array}{l}\text { Surgical } \\
\text { resection or } \\
\text { radiotherapy }\end{array}$ & $\begin{array}{l}\text { Surgical } \\
\text { excision }\end{array}$ & $\begin{array}{c}\text { Surgical } \\
\text { resection and } \\
\text { chemotherapy/ } \\
\text { radio- therapy }\end{array}$ & $\begin{array}{c}\text { Surgical } \\
\text { resection and } \\
\text { radiotherapy }\end{array}$ & $\begin{array}{c}\text { Resection, } \\
\text { none, if } \\
\text { asymptomatic }\end{array}$ & Surgical excision \\
\hline Prognosis & $\begin{array}{c}40-50 \% \\
\text { recurrences, } \\
20 \% \text { mortality }\end{array}$ & $\begin{array}{c}50 \% \\
\text { recurrence } \\
\text { within } 1 \text { year }\end{array}$ & $\begin{array}{l}\text { spontaneous } \\
\text { regression } \\
\text { or rapid } \\
\text { propression }\end{array}$ & $\begin{array}{l}\text { Overall survival } \\
6 \text { months }\end{array}$ & $\begin{array}{l}\text { Median } \\
\text { survival } 13 \\
\text { months }\end{array}$ & good & $\begin{array}{l}\text { Systemic or CNS } \\
\text { affection }\end{array}$ \\
\hline
\end{tabular}

Figure 1: Pathological and clinical findings of histiocytic and dendritic sarcoma $[10,14,15]$.

Surgery, radiation and chemotherapy are the therapeutic options. Unfortunately, because of the rareness of these malignancies, structured therapy algorithms do not exist. Even the problem of primary surgery, radiation, chemotherapy, or combined therapy is not solved. Many chemotherapy- schemes are reported in former studies, although the therapeutic value is not known as well. Saygin et al. [6] show in a pooled analysis of 462 case reports about dendritic cell sarcoma no benefit for adjuvant modalities. However, the tendency for using the CHOEP-scheme (Cyclophosphamide, Hydroxydanuorubicin, Vincristine, Etoposid, Prednisolone) seems to be effective especially in HS [7-9].

New molecular genetic studies discovered mutations in the RAS-RAF-MEK-ERK pathway which induced new diagnostic and therapeutic options. Hence, new BRAF- inhibitors such as cobimetinib (Cotellic®) vemurafenib (Zelboraf®), dabrafenib (Tafinlar $\AA$ ), and encorafenib (Braftovi ${ }^{\circledR}$ ) seem to be a promising approach before or after surgery/ radiation if mutational analysis is positive [10-13]. Therefore, choosing the first line treatment for histiocytic or dendritic cell neoplasms remains a high individual decision that should take into account tumor growth, location, infiltration in vessels or nerves, patients' co-morbidities, and presence of mutations in the RAS-RAF-MEK-ERK pathway. Primary surgical therapy followed by a chemotherapy or MEK inhibitor therapy might be a useful strategy. However, prospective well- designed research is urgently needed to understand the tumorbiology and to improve the therapy. We recommend that patients with Histiocytic and Dendritic sarcoma should be treated in a specialized sarcoma and cancer center to get an early and sufficient diagnosis and therapy $[14,15]$.

\section{References}

1. WHO Classification (2015) Tumours of the Haematopoietic and Lymphoid Tissues (2008). In: Hoffbrand AV, Higgs DR, et al. (Eds.) Postgraduate Haematology, Oxford, John Wiley \& Sons, Ltd; UK, pp. 885887.

2. Shao H, Xi L, Raffeld M, Feldman AL, Ketterling RP, et al. (2011) Clonally related histiocytic/dendritic cell sarcoma and chronic lymphocytic leukemia/small lymphocytic lymphoma: A study of seven cases. Mod Pathol 24(11): 1421-1432.

3. Pileri SA, Grogan TM, Harris NL, Banks P, Campo E, et al. (2002) Tumours of histiocytes and accessory dendritic cells: an immunohistochemical approach to classification from the International Lymphoma Study Group based on 61 cases. Histopathology 41(1): 1-29.

4. Gounder M, Desai V, Kuk D, Agaram N, Arcila M, et al. (2015) Impact of surgery, radiation and systemic therapy on the outcomes of patients with dendritic cell and histiocytic sarcomas. Eur J Cancer 51(16): 24132422.

5. Dalia S, Jaglal M, Chervenick P, Cualing H, Sokol L (2014) Clinicopathologic characteristics and outcomes of histiocytic and dendritic cell neoplasms: The moffitt cancer center experience over the last twenty-five years. Cancers (Basel) 6(4): 2275-2295. 
6. Saygin C, Uzunaslan D, Ozguroglu M, Senocak M, Tuzuner N (2013) Dendritic cell sarcoma: a pooled analysis including 462 cases with presentation of our case series. Crit Rev Oncol Hematol 88(2): 253-271.

7. Carboni F, Covello R, Bertini L, Valle M (2021) Uncommon retroperitoneal tumour: follicular dendritic cell sarcoma. Acta Chir Belg 121(3): 219221.

8. Sasaki M, Izumi H, Yokoyama T, Kojima M, Hosono A (2017) Follicular dendritic cell sarcoma treated with a variety of chemotherapy. Hematol Oncol 35(4): 905-908.

9. Schlick K, Aigelsreiter A, Pichler M, Reitter S, Neumeister P, et al. (2012) Histiocytic sarcoma - targeted therapy: Novel therapeutic options? A series of 4 cases. Onkologie 35(7-8): 447-450.

10. Pan Z, Xu ML (2019) Histiocytic and dendritic cell neoplasms. Surg Pathol Clin 12(3): 805-829.

11. Venkataraman V, Massoth LR, Sullivan RJ, Friedmann AM (2020) Secondary histiocytic sarcoma with BRAF(V600E) mutation after T-cell acute lymphoblastic leukemia in a very young child with dramatic response to dabrafenib and trametinib. Pediatr Blood Cancer 67(5): e28200.

12. Gouravan S, Meza-Zepeda LA, Myklebost O, Stratford EW, Munthe E (2018) Preclinical evaluation of vemurafenib as therapy for BRAF (V600E) mutated sarcomas. Int J Mol Sci 19(4): 969.

13. Diamond EL, Durham BH, Ulaner GA, Drill E, Buthorn J, et al. (2019) Efficacy of MEK inhibition in patients with histiocytic neoplasms. Nature 567(7749): 521-524.

14. O’Malley DP, Agrawal R, Grimm KE, Hummel J, Glazyrin A, et al. (2015) Evidence of BRAF V600E in indeterminate cell tumor and interdigitating dendritic cell sarcoma. Ann Diagn Pathol 19(3): 113-116.

15. Dalia S, Shao H, Sagatys E, Cualing H, Sokol L (2014) Dendritic cell and histiocytic neoplasms: biology, diagnosis, and treatment. Cancer Control 21(4): 290-300. 